\title{
THE SURGICAL TREATMENT OF PRESSUE SORES IN SPINAL INJURIES
}

\author{
By I. M. NuSEIBEH, F.R.C.S. and W. EL-MaSRI, F.R.C.S. \\ National Spinal Injuries Centre, Stoke Mandeville Hospital, Aylesbury
}

PRESSURE sores remain one of the most common serious complications of spinal cord injury. It is also known that during the life of a paraplegic he will be exposed from time to time to circumstances which make him ignore his skin care, such as contracting an illness and especially if he is admitted into a general hospital or involvement in domestic problems etc. Therefore, the risks of developing pressure sores more than once is always present. It is from this basic understanding that the treatment of pressure sores in our centre is mainly conservative. Vigilant efforts to make the patient fully aware of such risks and the early seeking of medical advice make this method fairly successful.

Unfortunately, a certain number of patients need radical surgical treatment for their sores. The indications for this treatment are: I. recurrent skin breakdown in the same area of the body; 2 . large sores which will take a long time to heal; 3. the existence of a discharging sinus with an underlying bursa; and 4. the presence of exposed infected bone.

Before any radical surgery is undertaken, slough is excised adequately and the sore is dressed daily until healthy granulation tissue starts to appear. Weekly swabs are taken for culture to aid us in eradicating the infection. When the sore becomes sterile, surrounded by healthy looking skin and free from induration and oedema, gentle massage is commenced to the skin area around it. This will render the skin supple and help it to regain its elasticity. Only at this stage is the sore ready for excision. For large sores where the skin edges cannot be approximated, split skin graft is applied as a first step. This procedure may prove curative on its own (Nuseibeh, I974). If not, the resulting scar will shrink, rendering the grafted sore smaller and more amenable to radical excision and direct closure.

In our experience we have found that the method of choice in the surgical management of sores is complete excision of the sore and the underlying bony prominence following the pseudo-tumour technique (Guttmann, I955) (Figs I, 2 and 3 ). The adoption of this method allowed us to cure these sores with the minimum disturbance of the surrounding soft tissue, to avoid unnecessary disfigurement and to give the patient a relatively small linear scar.

\section{Method}

The sore is packed when possible with ribbon gauze and then closed with a stitch or two. An elliptical incision is made around the edges of the sore which is then dissected down to the underlying prominent bone and excised. All parts of the sore must be removed. The underlying bone is also excised except in the case of sacral sores where the sacrum is gently shaved. Tension is allowed only during closure of the innermost soft tissue layer which is approximated as much as possible. This usually brings the rest of the soft tissue layers together. Closure is then meticulously completed without tension. Sacral sores are closed using only full thickness skin since muscle layers cannot be created without extensive 


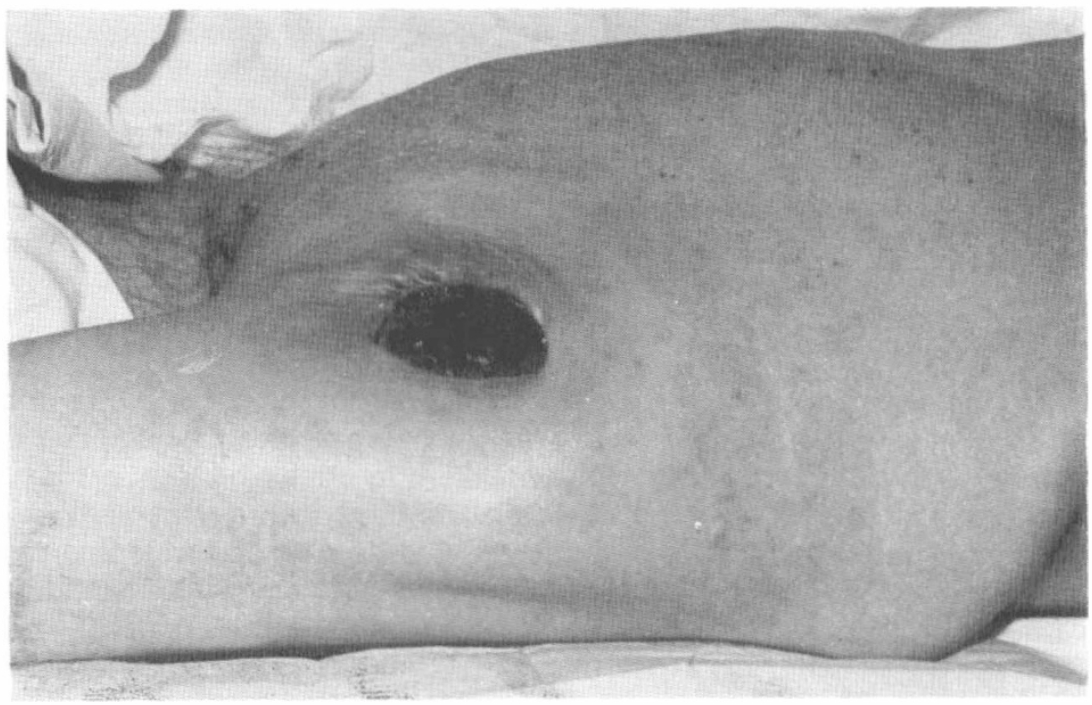

FIG. I

Right Trochanteric sore.
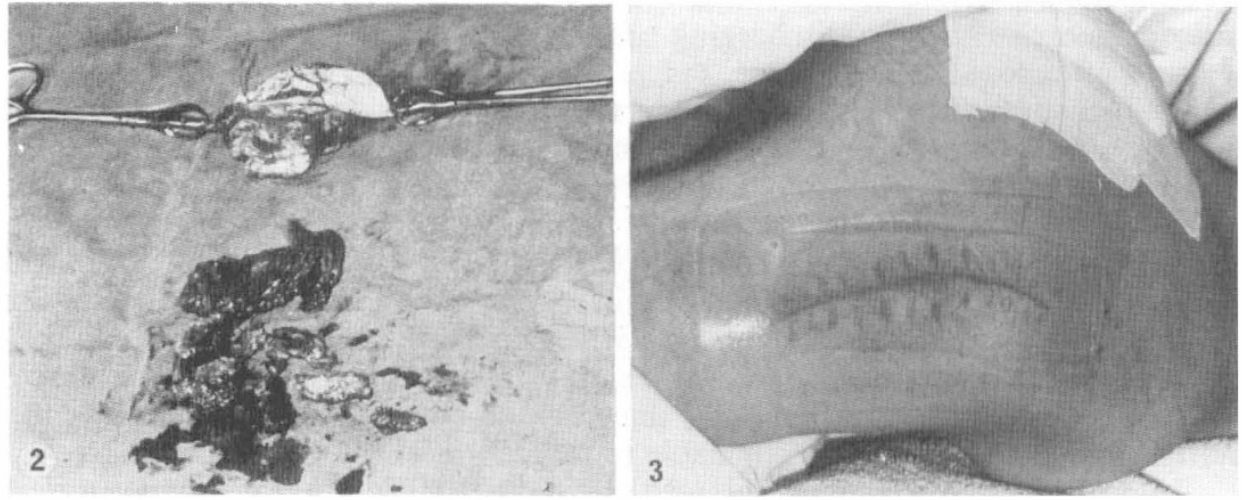

FIG. 2

Excision of right Trochanteric sore by Pseudo-Tumour Technique.

FIG. 3

Two weeks following excision of right trochanteric sore.

dissection. One o Dexon is used to the muscle and subcutaneous layers and II o nylon for the skin. Suction drain is always left to come out through a separate hole. The patient is kept in bed for a period of 3 weeks during which he could lie on all sides of his body apart from the operation site. Following this he is allowed to sit up gradually and by the end of the fourth week he is ready for discharge (Figs 4 and 5).

\section{Material}

We have surveyed all our patients who had radical surgical treatment for 1heir pressure sores from the period October 1973 to June 1977. All these patients 


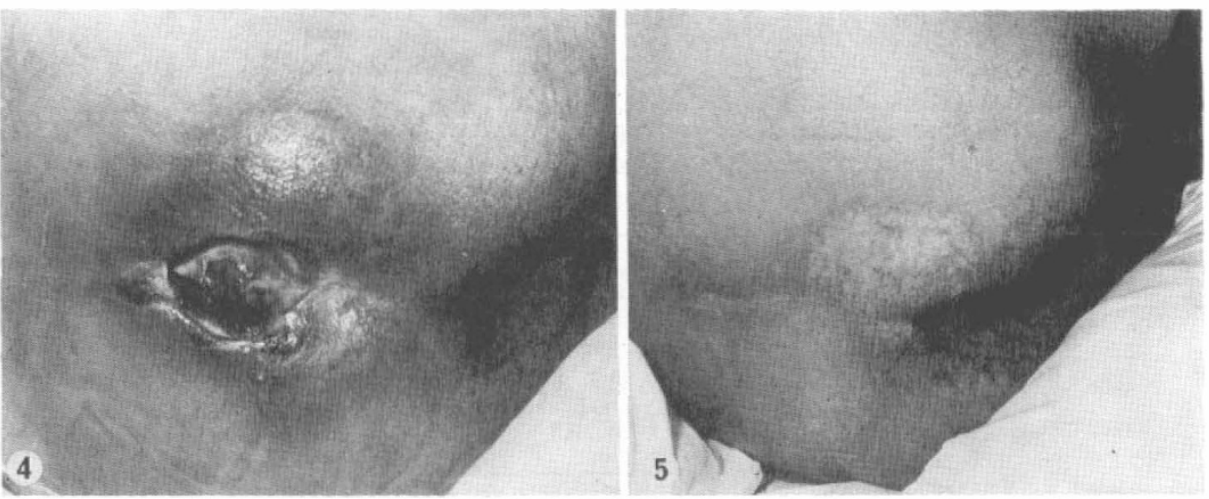

FIG. 4

Sacral sore.

Fig. 5

After excision and shaving of the sacrum, patient ready for discharge.

had the sore excised with the underlying bony prominence followed by direct closure. If the sore recurred within the first year after the operation, we considered this a failure. On the other hand if the sore was cured or recurrence did not appear until more than a year later, we considered this a success.

The number of patients surveyed was 260 of which 80 per cent were males and 20 per cent were female (Table I).

The lesions of these patients were (Table II): lumbar, 30 (II per cent); thoracic, I8I (70 per cent); cervical, 49 (I9 per cent).

The types of sore were (Table III): sacral, 48 (I8.5 per cent); ischial, I30 (50 per cent); trochanteric, $82(3 \mathrm{I} \cdot 5$ per cent).

TABLE I

\begin{tabular}{ccc}
\hline No. of patients & No. of male & No. of female \\
\hline 260 & 207 & 53 \\
\hline
\end{tabular}

TABLE II

Type of lesions

\begin{tabular}{|c|c|c|c|c|c|}
\hline \multicolumn{2}{|c|}{ Lumbar } & \multicolumn{2}{|c|}{ Thoracic } & & ical \\
\hline \multicolumn{2}{|c|}{30} & \multicolumn{2}{|c|}{ I $8 I$} & \multicolumn{2}{|c|}{49} \\
\hline $\begin{array}{c}\text { complete } \\
27\end{array}$ & $\begin{array}{c}\text { incomplete } \\
3\end{array}$ & $\begin{array}{c}\text { complete } \\
\text { I73 }\end{array}$ & $\underset{8}{\text { incomplete }}$ & $\underset{30}{\text { complete }}$ & $\begin{array}{c}\text { incomplete } \\
\text { I9 }\end{array}$ \\
\hline
\end{tabular}

\section{Results}

In this series we have found that the number of successes, i.e. cured, was 244 (93.85 per cent) and the number of failures were I 6 ( $6 \cdot$ I 5 per cent) (Table IV). 
TABLE III

Types of pressure sores

\begin{tabular}{|c|c|c|c|c|c|}
\hline \multicolumn{2}{|c|}{ Sacral } & \multicolumn{2}{|c|}{ Ischial } & \multicolumn{2}{|c|}{ Trochanteric } \\
\hline \multicolumn{2}{|c|}{$48(18 \cdot 5 \%)$} & 130 & $0 \%)$ & \multicolumn{2}{|c|}{$82(3 \mathrm{I} \cdot 5 \%)$} \\
\hline 37 male & I I female & Ioo male & 30 female & 70 male & I2 female \\
\hline
\end{tabular}

TABLE IV

Results

\begin{tabular}{cc}
\hline No. of successes & No. of failures \\
\hline $244(93.85 \%)$ & I6 $(6.15 \%)$ \\
\hline
\end{tabular}

Out of these only seven patients ( 2.8 per cent) had to be re-operated upon, while the rest had their complications healed conservatively.

\section{Discussion}

Two hundred and sixty patients received radical excision and direct closure to their sacral, ischial and trochanteric sores. Other sores are omitted in this study. In our survey the failure rate (6.15 per cent) is so low that it compares favourably with the other surgical procedures, i.e. the use of flaps (Bailey, I970, Krupp \& Zach, 1976). This rate of failure is attributed to the following causes:

I. Carelessness of the patient, e.g. neglecting to lift himself or change his position frequently; 2 . spasticity and spasm especially in the immediate postoperative period; 3 . contractures and difficult positioning; 4 . poor nursing care; and 5. technical faults in the surgical management such as excision of the sore prematurely, sepsis and inadequate removal of the prominent underlying bone. lower.

Better understanding of the above factors could bring the failure rate even

\section{Conclusion}

Radical excision of the pressure sore with the underlying prominent bone followed by direct closure gives the patient a relatively small scar, causes little disfigurement and does not disturb the surrounding soft tissue. Thus recurrence can more easily be treated than if large areas of tissue have been disturbed by the previous use of a flap.

\section{RÉSUMÉ}

L'excision radicale des ulcers avec les prominences osseuses suivi par la cloture directe donne au para-tetra-plegique une petite circatricem causant un disfigurement minime et ne derange pas les tissus alentours.

Le traitement de la recidive sera donc plus facile que si une grande surface des tissus auraient ete mobilises par l'usage des lambeaux. 


\section{ZUSSAMENFASSUNG}

Radikale Excision von Decubiti mit unterliegenden prominenten Knochen gefolgt von direkten Verschluss der Wunde, gibt eine relative kleine Narbe, geringe Narbe und stört auch nicht die unterliegende Gewebe. So können Rezidive leichter behandelt werden im Vergleich von Transplantationen.

Acknowledgements. We wish to thank Mrs Sylvia Nicol, Miss D. Franch, Mrs Janet Rowe and the staff of the Spinal Office for their secretarial help.

\section{REFERENCES}

BaIley, B. N. (1970). Bedsores. Brit. F. Hosp. Med., 3, 223-23I.

GutTMANN, L. (1955). Problems of treatment of pressure sores in spinal paraplegics. Brit. F. Plast. Surg., 8, 196-213.

KRUPP, S. \& ZACH, G. A. (I976-77). Operative treatment of pressure sores in paraplegics by rotation flap. Paraplegia, 14, 29-35.

Nuseibeh, I. M. (I974-75). Split skin graft and the treatment of pressure sores. Paraplegia, I2, I-4. 